\title{
Expansion of adult $\beta$-cell mass in response to increased metabolic demand is dependent on HNF-4a
}

\author{
Rana K. Gupta, ${ }^{1,3}$ Nan Gao, ${ }^{1,3}$ Regina K. Gorski, ${ }^{1,2}$ Peter White, ${ }^{1}$ Olga T. Hardy, ${ }^{1}$ Kiran Rafiq, ${ }^{1}$ \\ John E. Brestelli, ${ }^{1}$ Guang Chen, ${ }^{2}$ Christian J. Stoeckert Jr., ${ }^{1,2}$ and Klaus H. Kaestner ${ }^{1,4}$ \\ ${ }^{1}$ Department of Genetics and Institute for Diabetes, Obesity, and Metabolism, University of Pennsylvania School of \\ Medicine, Philadelphia, Pennsylvania 19104, USA; ${ }^{2}$ Center for Bioinformatics, University of Pennsylvania School of \\ Medicine, Philadelphia, Pennsylvania 19104, USA
}

The failure to expand functional pancreatic $\beta$-cell mass in response to increased metabolic demand is a hallmark of type 2 diabetes. Lineage tracing studies indicate that replication of existing $\beta$-cells is the principle mechanism for $\beta$-cell expansion in adult mice. Here we demonstrate that the proliferative response of $\beta$-cells is dependent on the orphan nuclear receptor hepatocyte nuclear factor- $4 \alpha(H N F-4 \alpha)$, the gene that is mutated in Maturity-Onset Diabetes of the Young 1 (MODY1). Computational analysis of microarray expression profiles from isolated islets of mice lacking $H N F-4 \alpha$ in pancreatic $\beta$-cells reveals that $\mathrm{HNF}-4 \alpha$ regulates selected genes in the $\beta$-cell, many of which are involved in proliferation. Using a physiological model of $\beta$-cell expansion, we show that $H N F-4 \alpha$ is required for $\beta$-cell replication and the activation of the Ras/ERK signaling cascade in islets. This phenotype correlates with the down-regulation of suppression of tumorigenicity 5 (ST5) in $H N F-4 \alpha$ mutants, which we identify as a novel regulator of ERK phosphorylation in $\beta$-cells and a direct transcriptional target of $\mathrm{HNF}-4 \alpha$ in vivo. Together, these results indicate that $\mathrm{HNF}-4 \alpha$ is essential for the physiological expansion of adult $\beta$-cell mass in response to increased metabolic demand.

[Keywords: Ras; extracellular regulated kinase; mitogen activated protein kinase; $\beta$-cells; HNF-4 $\alpha$; type 2 diabetes; gestational diabetes]

Supplemental material is available at http://www.genesdev.org.

Received January 26, 2007; revised version accepted February 9, 2007.

Diabetes mellitus is a metabolic disorder that currently affects $>150$ million people worldwide. This number is predicted to grow to as many as 300 million people by the year 2025 (Zimmet et al. 2001). The disease can be characterized by either absolute insulin deficiency due to the autoimmune destruction of pancreatic insulinproducing $\beta$-cells (type 1 diabetes mellitus), or relative insulin deficiency due to defective insulin secretion and/ or insulin sensitivity (type 2 diabetes mellitus). The resulting hyperglycemia can ultimately result in organ failure and death.

Insulin production is limited to the endocrine pancreas, a micro-organ within the exocrine pancreas consisting of the islets of Langerhans. The pancreatic islets comprise $<5 \%$ of the total pancreatic volume, and themselves are composed of five endocrine cell types: glucagon-producing $\alpha$-cells, insulin-producing $\beta$-cells, somatostatin-producing $\delta$-cells, ghrelin-producing $\varepsilon$-cells,

\footnotetext{
${ }^{3}$ These authors contributed equally to this work.

${ }^{4}$ Corresponding author.

E-MAIL kaestner@mail.med.upenn.edu; FAX (215) 573-5892.

Article is online at http://www.genesdev.org/cgi/doi/10.1101/gad.1535507.
}

and pancreatic polypeptide-producing PP cells. The importance of gene transcription in the regulation of $\beta$-cell growth and function is highlighted by the genetic and molecular analysis of Maturity-Onset Diabetes of the Young (MODY). MODY, an autosomal dominantly inherited form of type 2 diabetes, results from mutations in at least six different genes. One of these encodes the glycolytic enzyme glucokinase (MODY2), which is an important glucose sensor, while all others encode transcription factors: Hepatocyte nuclear factor $(H N F)-4 \alpha$ (MODY1); HNF-1 $\alpha$ (MODY3); insulin promoter factor-1 (IPF1/Pdx-1; MODY4); HNF-1 $\beta$ (MODY5); and neurogenic differentiation factor 1 (NeuroD1; MODY6) (Shih and Stoffel 2002). MODY transcription factors represent crucial links in a transcriptional hierarchy that controls both the specification of endocrine cell types during early pancreatic development as well as the maintenance of the differentiated state in the adult (Jonsson et al. 1994; Ahlgren et al. 1998; Wang et al. 1998, 2000, 2004; Hagenfeldt-Johansson et al. 2001; Fukui et al. 2005; Gupta et al. 2005; Miura et al. 2006). Complementing the molecular identification of the MODY transcription factors by human genetics, developmental biologists 
have elucidated regulatory pathways by targeted disruption of the genes encoding pancreatic-enriched transcription factors, and by the analysis of the expression patterns of these genes (Wilson et al. 2003). A detailed understanding of how these transcription factors and their downstream targets govern $\beta$-cell differentiation in vivo is essential in order to effectively manipulate these processes as a therapeutic strategy for diabetes.

Among the transcription factors required for the maintenance of the adult $\beta$-cell is the orphan nuclear receptor hepatocyte nuclear factor- $4 \alpha$ (HNF-4 $\alpha$ ). Targeted disruption of $H N F-4 \alpha$ in $\beta$-cells results in impaired glucose tolerance due to attenuated glucose-stimulated insulin secretion (Gupta et al. 2005; Miura et al. 2006). This can be explained, in part, by a defect in the function of the ATP-sensitive potassium channel $\left(\mathrm{K}_{\mathrm{ATP}}\right)$, a central component of the glucose-sensing machinery. Both studies reported that $\beta$-cells devoid of HNF- $4 \alpha$ exhibit only few changes in the expression of genes involved in regulating insulin secretion (Gupta et al. 2005; Miura et al. 2006). However, the effects of HNF- $4 \alpha$ deficiency on global gene expression in the $\beta$-cell have not been explored.

Therefore, in order to determine the molecular networks controlled by HNF- $4 \alpha$, we sought to identify all of its targets, whether regulated directly or indirectly, by comparing gene expression profiles of $H N F-4 \alpha^{\operatorname{loxP} / \text { loxP }}$; Ins.Cre mice to those of littermate controls. Gene expression analysis revealed that numerous genes and pathways involved in the regulation of $\beta$-cell proliferation are dependent on HNF- $4 \alpha$. As a result, $H N F-4 \alpha^{\text {loxP } / \text { loxP }}$;Ins.Cre mice fail to expand $\beta$-cell mass in response to increased metabolic demands. Moreover, our analysis indicates that Ras/ERK signaling in the $\beta$-cell is dependent on HNF- $4 \alpha$. This defect can be explained in part by the down-regulation of suppression of tumorigenicity $5(S T 5)$ in islets of $H N F-4 \alpha^{\operatorname{loxP} / \operatorname{loxP}}$; Ins.Cre mice, which we identify as a novel regulator of ERK activation in $\beta$-cells and a direct transcriptional target of HNF- $4 \alpha$ in vivo.

\section{Results}

$H N F-4 \alpha$ regulates proliferative pathways in the $\beta$-cell

In order to identify targets of HNF-4 $\alpha$ in the $\beta$-cell, we performed large-scale expression profiling on pancreatic islets from 4-mo-old HNF-4 ${ }^{\text {loxP } / 10 \times P} ;$ ins.Cre mice in which HNF- $4 \alpha$ is deleted in $\sim 85 \%$ of $\beta$-cells (Gupta et al. 2005). This microarray expression analysis identified 128 significantly up-regulated and 57 significantly downregulated genes in HNF- $4 \alpha$ mutants (Fig. 1A; Supplementary Table 1). Using quantitative real-time PCR, we confirmed 13 of $14(92 \%)$ randomly chosen differentially expressed genes as HNF- $4 \alpha$-dependent, as expected by the $10 \%$ false discovery rate chosen in the initial analysis (Fig. 1B). However, the expression levels of the vast majority $(98 \%)$ of the genes expressed in pancreatic islets were not significantly modulated by the absence of HNF- $4 \alpha$.

To elucidate the physiological processes in the $\beta$-cell that are dependent on HNF- $4 \alpha$, we first determined the Gene Ontology functions for the differentially expressed
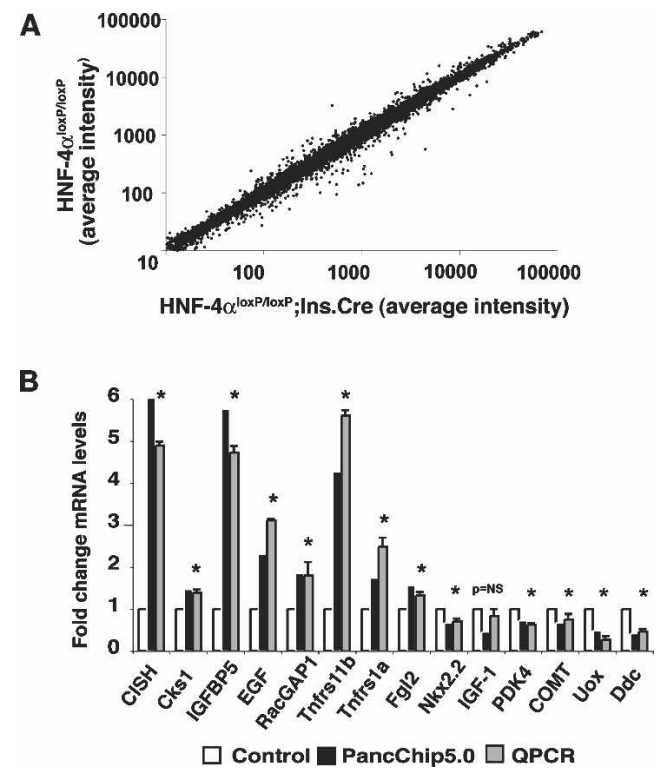

Figure 1. Gene expression profiling of $H N F-4 \alpha^{10 \times P / l o x P}$ ins.Cre mice. Total RNA was prepared from isolated islets of 4- to 5-mo-old control and mutant mice. The RNA was amplified, fluorescently labeled, and hybridized to the PancChip 5.0 cDNA microarray. (A) A scatterplot of average intensity values for all expressed genes illustrates that the vast majority of genes were not differentially expressed. Approximately 2\% of expressed genes (128 genes significantly up-regulated and 57 significantly down-regulated) were differentially expressed in HNF- $4 \alpha$ mutant islets $\left(n=5 H N F-4 \alpha^{\operatorname{loxP} / \operatorname{loxP},} n=3\right.$ $H N F-4 \alpha^{\operatorname{lox} P / / \operatorname{lox} P}$; Ins.Cre). (B) Quantitative real-time PCR confirmation of differentially expressed genes. Total RNA was extracted from isolated islets of a second cohort of animals, and cDNA derived from unamplified RNA was used for PCR. Thirteen of $14(92 \%)$ genes were confirmed as differentially expressed, consistent with the $10 \%$ FDR setting chosen for microarray analysis ( $n=4-6$ for PCR). $\left(^{*}\right) p$-value from Student's $t$-test $<0.05$.

genes in HNF-4 $\alpha^{\operatorname{loxP} / \operatorname{loxp}} ;$ ins. Cre mice (Table 1). Consistent with the known functions of HNF-4 $\alpha$ in the liver, the largest percentage of HNF- $4 \alpha$-regulated genes are involved in metabolism (Hayhurst et al. 2001; Parviz et al. 2003). However, an almost equal number of differentially expressed genes function in signal transduction and cell proliferation. These results were surprising since $\beta$-cell mass was unchanged in 4-mo-old HNF$4 \alpha^{\operatorname{loxP} / \text { loxp }} ;$ Ins.Cre (Gupta et al. 2005; Miura et al. 2006), and the frequency of proliferative and apoptotic $\beta$-cells in adult mutants was indistinguishable from controls (data not shown). In addition, thus far a direct role for HNF- $4 \alpha$ in the regulation of $\beta$-cell proliferation has not been reported. Nevertheless, our gene expression analysis suggested that HNF- $4 \alpha$ mutants might display impaired $\beta$-cell growth in response to proliferative stimuli.

\section{HNF-4 $\alpha$ is required for the expansion of maternal} $\beta$-cell mass during pregnancy

Assessing the rate of $\beta$-cell proliferation and cell death in the pancreatic islet is challenging given the low rate of 
Table 1. Gene Ontology (GO) functions of genes regulated by $H N F-4 \alpha$

\begin{tabular}{|c|c|c|}
\hline $\begin{array}{l}\text { Level } 2 \text { GO } \\
\text { function }\end{array}$ & Level 3 GO function & $\begin{array}{l}\text { Number } \\
\text { of genes }\end{array}$ \\
\hline \multirow[t]{14}{*}{ Metabolism } & & 57 \\
\hline & $\begin{array}{l}\text { Organic acid } \\
\text { metabolism }^{\mathrm{a}}\end{array}$ & 12 \\
\hline & Protein metabolism & 20 \\
\hline & Biosynthesis & 12 \\
\hline & $\begin{array}{l}\text { Nucleic acid } \\
\text { metabolism }\end{array}$ & 12 \\
\hline & $\begin{array}{l}\text { Carbohydrate } \\
\text { metabolism }^{\mathrm{a}}\end{array}$ & 9 \\
\hline & Catabolism & 11 \\
\hline & Amine metabolism ${ }^{\mathrm{a}}$ & 8 \\
\hline & $\begin{array}{l}\text { Amino acid } \\
\text { metabolism }^{\mathrm{a}}\end{array}$ & 7 \\
\hline & Lipid metabolism & 5 \\
\hline & Alcohol metabolism & 4 \\
\hline & $\begin{array}{l}\text { Phosphorus } \\
\text { metabolism }\end{array}$ & 5 \\
\hline & $\begin{array}{l}\text { Metabolism of } \\
\text { aromatics }^{\mathrm{a}}\end{array}$ & 4 \\
\hline & Electron transport & 3 \\
\hline \multirow{2}{*}{$\begin{array}{l}\text { Cellular physiological } \\
\text { process }\end{array}$} & & 29 \\
\hline & $\begin{array}{l}\text { Cell growth and/or } \\
\text { maintenance }\end{array}$ & 22 \\
\hline \multirow[t]{3}{*}{ Cell communication ${ }^{\mathrm{a}}$} & & 29 \\
\hline & Signal transduction & 21 \\
\hline & Cell adhesion & 8 \\
\hline \multirow{2}{*}{$\begin{array}{l}\text { Organismal } \\
\text { physiological } \\
\text { process }\end{array}$} & & 8 \\
\hline & $\begin{array}{l}\text { Neurophysiological } \\
\text { process }\end{array}$ & 3 \\
\hline \multirow[t]{2}{*}{ Morphogenesis } & & 7 \\
\hline & Organogenesis & 7 \\
\hline \multirow[t]{2}{*}{ Response to stimulus } & & 6 \\
\hline & $\begin{array}{l}\text { Response to external } \\
\text { stimulus }\end{array}$ & 5 \\
\hline \multirow[t]{2}{*}{ Death } & & 5 \\
\hline & $\begin{array}{l}\text { Programmed cell } \\
\text { death }\end{array}$ & 5 \\
\hline
\end{tabular}

a Statistical overrepresentation as determined by EASE.

Only Level 2 GO categories represented by five or more genes are shown.

$\beta$-cell turnover in the adult mouse (Finegood et al. 1995). As a result, determination of $\beta$-cell turnover under stressful metabolic conditions is often required to uncover the effects of mutations affecting $\beta$-cell proliferation or apoptosis. Such an approach has been used successfully to delineate the role of $P d x-1$ (MODY4), IGF-1, and the GLP-1 receptor in cell proliferation and cell death (Johnson et al. 2003; Li et al. 2003; Lu et al. 2004). Given the changes in expression of genes involved in cell growth in HNF-4 $\alpha$ mutants, we hypothesized that HNF$4 \alpha$ plays a role in $\beta$-cell replication in response to mitogenic signals. Several experimental paradigms can be used to stimulate $\beta$-cell proliferation such as partial pancreatectomy, high fat diet feeding, or pharmacological treatment of isolated islets. However, one of the most robust and physiologic stimuli of $\beta$-cell proliferation is pregnancy. In order to compensate for the acquired insulin resistance present during gestation, $\beta$-cell mass increases to meet metabolic demands. Studies in rats indicate that $\beta$-cell proliferation increases dramatically during pregnancy, with peak bromodeoxyuridine (BrdU) labeling occurring at about two-thirds of the way through the gestational period (Parsons et al. 1992). Thus, the pregnancy model for $\beta$-cell compensation provides a robust, highly reproducible, and specific model to test our hypothesis that $\mathrm{HNF}-4 \alpha$ regulates $\beta$-cell proliferation.

We first examined BrdU labeling of islet nuclei in control and HNF-4 $\alpha$ mutant females at day 14.5 of gestation (Fig. 2A-D). Labeling of islet nuclei was variable in control animals with almost all islets containing at least one BrdU-positive cell, but many containing five to $10 \mathrm{BrdU}$ positive cells. In contrast, nearly all islets in the HNF- $4 \alpha$ mutant mice contained fewer than two BrdU-positive cells. On average, $\sim 0.9 \%$ of all islet nuclei were BrdU positive in pancreata from either $H N F-4 \alpha^{\operatorname{lox} / \operatorname{loxP}}$ or HNF- $4 \alpha^{+/+}$;Ins.Cre controls. However, only $0.3 \%$ of the islet nuclei were labeled in pregnant $\mathrm{HNF}-4 \alpha$ mutants (Fig. 2E). Thus, we conclude that HNF-4 $\alpha$ is required for the normal increase in $\beta$-cell proliferation during pregnancy.

In order to determine if the decrease in $\beta$-cell proliferation in pregnant HNF- $4 \alpha$ mutant mice results in a reduction in $\beta$-cell mass, we assessed $\beta$-cell mass and islet area in both pregnant control and pregnant HNF$4 \alpha^{\text {loxP/loxP }} ;$ Ins.Cre mice. We found that $\beta$-cell mass in 4-mo-old pregnant $H N F-4 \alpha^{\text {loxP/loxP }}$;Ins.Cre mice was $\sim 50 \%$ of the $\beta$-cell mass of $H N F-4 \alpha^{\operatorname{loxP} / \operatorname{loxP}}$ or $H N F-4 \alpha^{+/+}$; Ins.Cre controls (Fig. 2F). Consistent with morphometric analysis, total pancreatic insulin content was also reduced by $>50 \%$ in pregnant $H N F-4 \alpha^{\operatorname{loxP} / \operatorname{loxP}} ;$ Ins. Cre mice when compared with either HNF-4 $\alpha^{\operatorname{loxP} / \operatorname{loxP}}$ or HNF-4 $\alpha^{+/+}$; Ins.Cre controls, further indicating a reduced endocrine compartment in pancreata of $H N F-4 \alpha^{10 x P / l o x P}$;Ins.Cre mice (Fig. 2G). While there was no statistically significant difference in islet density, we found fewer large islets in mutant pancreata when compared with controls (Fig. 2H). Thus, it appears likely that the reduction in $\beta$-cell mass in HNF- $4 \alpha$ mutants is due to the decrease in $\beta$-cell proliferation within existing islets.

Next, we investigated whether the reduced $\beta$-cell mass in HNF- $4 \alpha$ mutants has an impact on the response to glucose challenge. As previously reported, due to defects in glucose-stimulated insulin release, virgin $\mathrm{HNF}-4 \alpha$ mutants are glucose-intolerant compared with virgin controls. However, in the pregnancy model, the impact of HNF- $4 \alpha$ deficiency on the immediate response to glucose challenge is more pronounced, suggesting that the reduction in $\beta$-cell mass in the HNF- $4 \alpha$ mutant mice further impairs glucose tolerance (Fig. 2I). 


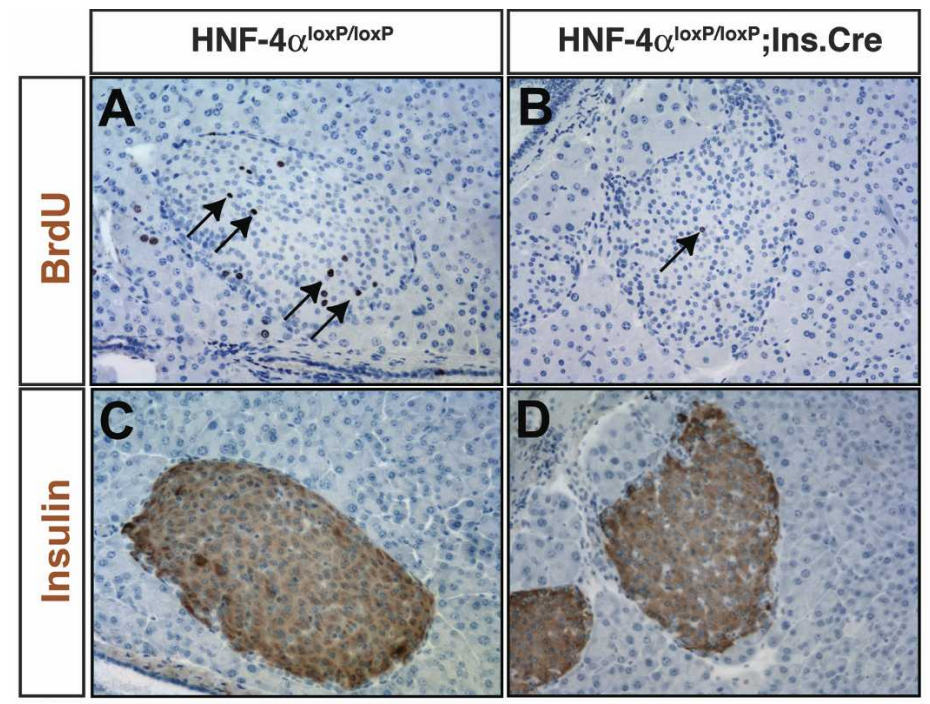

E

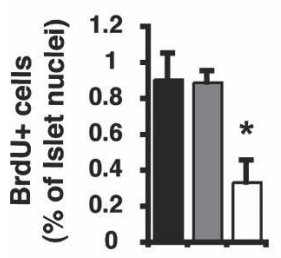

$\mathbf{F}$

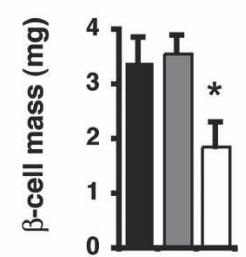

G

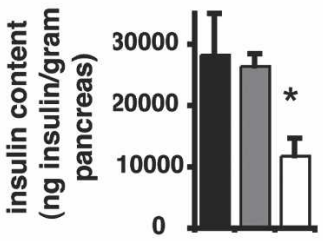

H

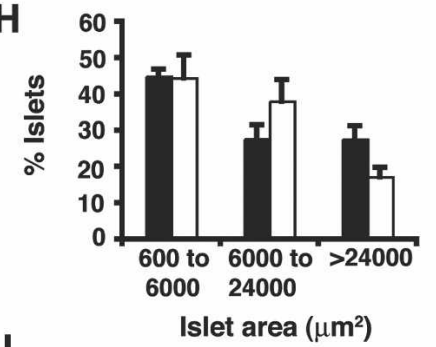

I
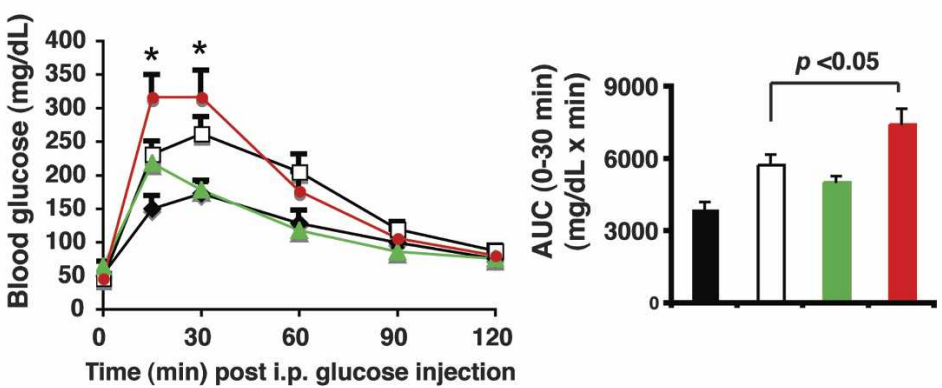

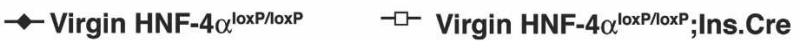

$$
\begin{aligned}
& \rightarrow \text { Pregnant HNF-4 } 4 \alpha^{\text {loxP/loxP }} \rightarrow \text { Pregnant HNF- } 4 \alpha^{\text {loxPloxP } ; \text { Ins.Cre }}
\end{aligned}
$$

Figure 2. HNF- $4 \alpha$ is required for $\beta$-cell expansion during pregnancy. BrdU staining of pancreata from 4to 5-mo-old pregnant $H N F-4 \alpha^{\operatorname{loxP} / \operatorname{loxP}} \quad(A)$ and $H N F-4 \alpha^{\text {loxP/loxp }}$;Ins.Cre $(B)$ mice. $(C, D)$ Insulin staining of adjacent sections indicates $\beta$-cells within the islet. (E) Percentage of islet nuclei staining positive for BrdU is lower in pregnant $H N F-4 \alpha^{\text {loxP/loxP }}$; Ins.Cre (white) mice when compared with pregnant $H N F-4 \alpha^{\operatorname{loxP} / \text { loxP }}$

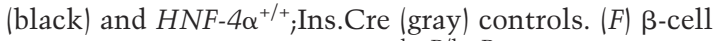
mass of pregnant $H N F-4 \alpha^{\operatorname{loxP} / 10 x P}$;Ins.Cre (white) mice is significantly lower than that of pregnant HNF$4 \alpha^{\text {loxP/loxP }}$ (black) and $H N F-4 \alpha^{+/+} ;$ins. Cre (gray) controls. $(G)$ Consistent with morphometric analysis, total pancreatic insulin content in pregnant $H N F-4 \alpha^{\text {loxP/loxP }}$;Ins. Cre (white) mice is reduced when compared with pregnant $H N F-4 \alpha^{\operatorname{loxP} / \text { loxP }}$ (black) and $H N F-4 \alpha^{+/+} ;$Ins.Cre (gray) controls. $(H)$ Distribution of islet size in HNF$4 \alpha^{\operatorname{loxP} / \operatorname{lox} P}$ (black) and HNF-4 $\alpha^{\operatorname{loxP} / \operatorname{loxP}} ;$ Ins.Cre (white) mice indicates fewer larger-sized islets in pregnant HNF- $4 \alpha$ mutants. Bars represent the mean \pm SEM; $n=3-4$ mice for each group for $A-H .\left(^{*}\right) p$-value from Student's $t$-test $<0.05$. (I) Glucose tolerance tests of virgin and pregnant $H N F-4 \alpha^{\operatorname{loxP} / \operatorname{loxP}}$ and $H N F-4 \alpha^{\operatorname{loxP} / \operatorname{loxP}}$; Ins.Cre mice. The area below the curve measurements (0-30 min) indicates that the impact of HNF- $4 \alpha$ deficiency on glucose tolerance is more pronounced in the pregnant state. The data represent the mean \pm SEM; $n=6-8$ mice for each group. $\left({ }^{\star}\right) p$-value from Student's $t$-test $<0.05$ when compared with pregnant controls.
Ras/ERK signaling is down-regulated in HNF-4 $\alpha$-deficient $\beta$-cells

In order to identify specific pathways that may be HNF$4 \alpha$-dependent and contribute to the observed growth defect, we combined our expression data with Gene Set Enrichment Analysis (GSEA), which is designed to detect subtle changes in the expression of groups of func- tionally related genes (Subramanian et al. 2005). Using GSEA, we identified several gene sets that are downregulated in HNF- $4 \alpha$-deficient islets (Table 2). Strikingly, many of the significantly down-regulated gene sets relate to cell proliferation, including the one associated with Ras signaling. Several studies suggest that Ras signaling is required for $\beta$-cell growth and participates in the response of pancreatic $\beta$-cells to prolactin during 
Table 2. GSEA

\begin{tabular}{|c|c|c|c|c|}
\hline Gene set & $\begin{array}{l}\text { Source or } \\
\text { reference }\end{array}$ & $\begin{array}{l}\text { Number of enriched } \\
\text { genes }\end{array}$ & $\begin{array}{l}\text { Gene } \\
\text { set size }\end{array}$ & $\begin{array}{c}\text { False discovery rate } \\
q \text {-value }\end{array}$ \\
\hline \multicolumn{5}{|l|}{ Glycolysis and } \\
\hline gluconeogenesis & GenMAPP & 2 & 25 & 0.13 \\
\hline Proteasome degradation & BioCarta & 2 & 27 & 0.15 \\
\hline Genes up-regulated in fetal & Manually curated (Broad & & & \\
\hline liver versus adult liver & Institute) & 22 & 49 & 0.15 \\
\hline $\begin{array}{l}\text { Cancer-related genes } \\
\text { involved in cell adhesion }\end{array}$ & & & & \\
\hline and metalloproteinases & Brentani et al. 2003 & 6 & 36 & 0.17 \\
\hline KRAS expression signature & Cordero et al. 2005 & 11 & 52 & 0.18 \\
\hline Insulin signaling & BioCarta & 9 & 60 & 0.19 \\
\hline Wnt signaling & BioCarta & 8 & 28 & 0.19 \\
\hline $\begin{array}{l}\text { Transcription factors } \\
\text { enriched in fetal liver }\end{array}$ & $\begin{array}{l}\text { Manually curated (Broad } \\
\text { Institute) }\end{array}$ & 7 & 41 & 0.19 \\
\hline $\begin{array}{l}\text { NFAT and hypertrophy of } \\
\text { the heart }\end{array}$ & BioCarta & 3 & 28 & 0.22 \\
\hline
\end{tabular}

Gene sets down-regulated In $H N F-4 \alpha^{10 x P / / 0 x P} ;$ Ins.Cre mice; FDR $\leq 0.25$.

pregnancy (Amaral et al. 2003, 2004). In addition, targeted disruption of the Ras activator RasGRF1 results in reduced $\beta$-cell proliferation and decreased $\beta$-cell mass (Font de Mora et al. 2003). When activated, Ras initiates a signal transduction cascade that culminates with the phosphorylation and activation of ERK1 and ERK2. Phosphorylated ERK then activates multiple substrates involved in the regulation of cellular proliferation and required for the mitogenic response of $\beta$-cells to growth factors (Burns et al. 2000). Thus, we hypothesized that Ras/ERK signaling in the $\beta$-cell is HNF- $4 \alpha$-dependent.

To test this hypothesis, we first examined the steadystate levels of activated Ras in isolated islets of control and HNF- $4 \alpha$ mutant mice. While no significant difference in Ras expression was observed between control and HNF- $4 \alpha$ islets (data not shown), levels of GTP-bound Ras in the mutant samples were $\sim 60 \%$ of the levels found in control islets, indicating that normal Ras activation in islets is HNF- $4 \alpha$-dependent (Fig. 3A). Next, we evaluated the dependence of ERK activation on HNF- $4 \alpha$ by measuring protein levels of phosphorylated ERK in control and HNF- $4 \alpha$-deficient islets following treatment with epidermal growth factor (EGF), a potent stimulus of Ras-dependent ERK activation. Incubation of freshly isolated islets from control mice with EGF resulted in an increase in phosphorylated ERK. However, in isolated islets of HNF- $4 \alpha$ mutants, both basal and stimulated levels of ERK phosphorylation were lower in comparison to controls (Fig. 3B). Total ERK1/2 levels were not changed between the two groups. To determine if ERK activation is HNF- $4 \alpha$-dependent during pregnancy, we evaluated both phosphorylated and total ERK protein levels in isolated islets of pregnant control and HNF- $4 \alpha$ mutant mice. Consistent with previous studies performed with pregnant rats, ERK phosphorylation increases dramatically in islets of pregnant mice, demonstrating activation of the ERK cascade (Fig. 3C). However, activation of ERK1 and ERK2 during pregnancy was significantly reduced in HNF- $4 \alpha$-deficient islets compared with con- trols (Fig. 3C). This attenuation of Ras/ERK signaling in HNF- $4 \alpha$-deficient $\beta$-cells provides a molecular explanation for the failure of these cells to proliferate when metabolically challenged.

\section{ST5 regulates ERK signaling in $\beta$-cells}

To identify the molecular link between HNF- $4 \alpha$ and Ras/ERK signaling, we searched for changes in gene expression of known regulators of this pathway. Microarray analysis showed that the transcript encoding ST5 is down-regulated in islets of HNF- $4 \alpha$ mutants. Sequence analysis indicates that ST5 contains regions homologous to known guanine exchange factors (Majidi et al. 1998). Overexpression of the p126 isoform of ST5 leads to increased ERK activation, suggesting a potential role for this factor in ERK pathway activation (Majidi et al. 1998). Real-time PCR confirmed that p126 ST5 mRNA is down-regulated by $60 \%$ in islets from HNF- $4 \alpha$ mutants (Fig. 3D), suggesting that reduced levels of ST5 could contribute to the observed decrease in ERK phosphorylation in HNF- $4 \alpha$ mutants.

In order to determine if ERK activation in $\beta$-cells is, indeed, ST5-dependent, we used RNA interference (RNAi) to down-regulate ST5 mRNA levels in MIN6 $\beta$-cells. Transduction of MIN6 cells with an adenovirus expressing short hairpin RNA (shRNA) targeting ST5 resulted in a $70 \%$ reduction in ST5 mRNA levels when compared with cells transduced with a scrambled shRNA construct (Fig. 3E). Suppression of ST5 expression resulted in lower basal and EGF-stimulated phospho-ERK protein levels compared with control cells (Fig. 3F). When normalized to total ERK by PhosphorImager analysis, phospho-ERK levels were reduced by more than twofold when ST5 expression was suppressed (data not shown). These data identify ST5 as a novel regulator of ERK signaling in $\beta$-cells and suggest that the down-regulation of ST5 expression in HNF- $4 \alpha$ mutant islets con- 
A
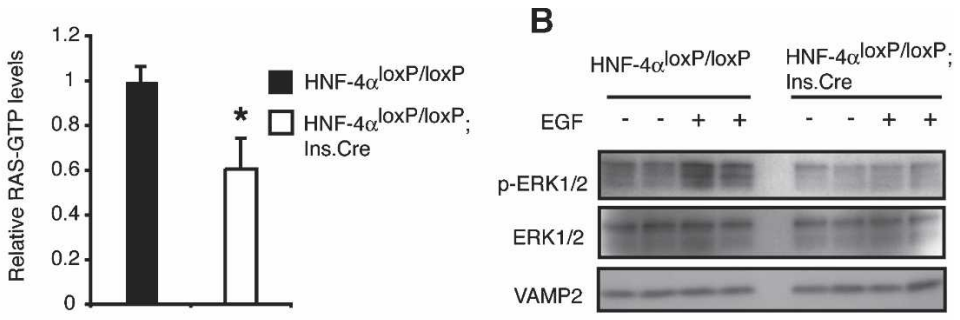

C

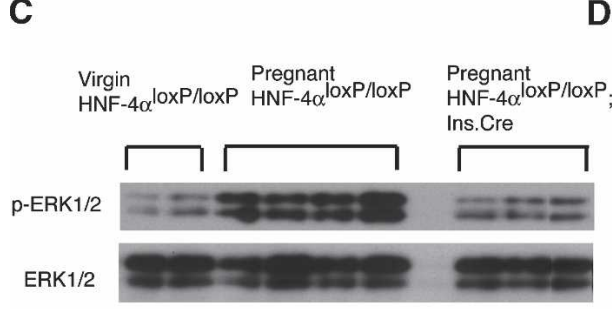

D

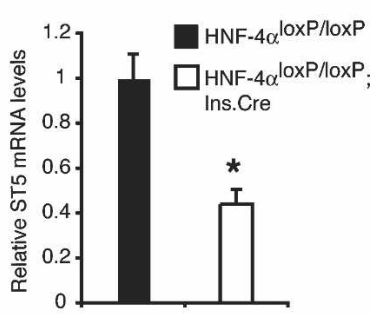

E

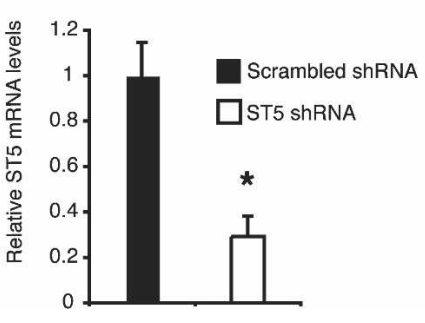

$\mathbf{F}$

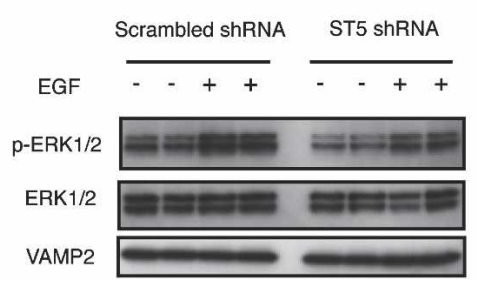

Figure 3. Ras/ERK signaling in $\beta$-cells is HNF- $4 \alpha$ dependent. (A) Ras-GTP ELISA indicates lower levels of activated Ras in freshly isolated islets from virgin HNF- $4 \alpha$ mutant mice in comparison to controls; $n=3$ for each group. (B) Western blot analysis indicates that EGF stimulation of ERK phosphorylation in isolated islets is HNF- $4 \alpha$ dependent. VAMP2 (vesicle-associated membrane protein 2) expression was used as a loading control. (C) Western blot analysis indicates that in freshly isolated islets of control mice, ERK1 and ERK2 phosphorylation increases dramatically during pregnancy but is significantly lower in pregnant HNF- $4 \alpha$-deficient islets. $(D)$ Real-time PCR analysis confirms microarray results indicating reduced mRNA levels of the ERK activator ST5 in isolated islets of HNF-4 $\alpha$ mutants; $n=6$ mice for each group. $(E)$ Adenoviral transduction of MIN6 cells with shRNA targeting ST5 results in $70 \%$ reduction in ST5 mRNA levels; $n=4$ for each group. $(F)$ Western blot analysis indicates that MIN6 cells with reduced expression of ST5 exhibit lower levels of basal and EGF-stimulated phosphorylated ERK. VAMP2 expression was used as a loading control. $\left({ }^{\star}\right) p$-value from Student's $t$-test $<0.05$.

tributes, at least in part, to the reduction of ERK activation caused by HNF- $4 \alpha$ deficiency.

ST5 is a direct transcriptional target of HNF-4 $\alpha$ in vivo

Next we investigated whether ST5 is a direct transcriptional target of HNF- $4 \alpha$ in vivo. We began by performing a computational analysis to locate putative HNF-4 $\alpha$ binding sites in the promoter of ST5. No high-scoring HNF- $4 \alpha$-binding site was present in the proximal promoter of the ST5 gene; however, a potential binding site was found $55 \mathrm{~kb}$ upstream of the transcriptional start site. In addition, we located a high-scoring HNF- $4 \alpha$ site $14 \mathrm{~kb}$ downstream from the promoter in intron 1 of the ST5 locus (Fig. 4A), in the orthologous area to where previous studies had revealed functional transcription factor-binding sites in the human ST5 gene (Lichy et al. 1996). In order to determine if HNF- $4 \alpha$ binds this site in vivo, we performed chromatin immunoprecipitation (ChIP) assays with isolated adult mouse islets. ChIP using an antibody raised against HNF- $4 \alpha$ followed by PCR revealed that HNF- $4 \alpha$, indeed, occupies the intronic region of ST5 containing the high-scoring HNF- $4 \alpha$-binding site (Fig. 4B). However, HNF-4 $\alpha$ did not occupy the potential site $-55 \mathrm{~kb}$ upstream of the first exon of ST5. To determine if HNF- $4 \alpha$ can occupy the binding site in intron 1 directly, we performed electrophoretic mobility shift assays (EMSA). Incubation of nuclear extract with a radiolabeled oligonucleotide containing the putative HNF- $4 \alpha$-binding sequence resulted in a strong shift of the radioactive band whose intensity was diminished with the addition of an unlabeled competitor oligonucleotide containing a known HNF- $4 \alpha$-binding site (Fig. 4C). Addition of a HNF-4 $\alpha$ antibody generated a supershifted band that was not observed with preimmune serum, indicating that the bound protein is, indeed, HNF- $4 \alpha$. To determine if this intronic element of the ST5 locus can function as an HNF- $4 \alpha$-dependent enhancer, we performed cotransfection assays with an 200-base-pair (bp) fragment of the conserved region containing the HNF- $4 \alpha$-binding site cloned into a luciferase promoter plasmid and an HNF- $4 \alpha$ expression vector. We found that overexpression of HNF- $4 \alpha$ resulted in increased luciferase activity, and that this transcriptional activation was nearly abolished when the HNF- $4 \alpha$-binding site was mutated (Fig. 4D). Together, these data indicate that ST5 is a direct transcriptional target of HNF- $4 \alpha$.

\section{HNF-4 $\alpha$ does not regulate the global transcriptional program in the pancreatic $\beta$-cell}

Prior global location analysis-that is, the large-scale determination of promoter occupancy by ChIP-had suggested HNF- $4 \alpha$ as a regulator of $>40 \%$ of genes actively transcribed in islets (Odom et al. 2004). Our expression profiling analysis indicates that HNF- $4 \alpha$ controls the expression of far fewer targets in the pancreatic $\beta$-cell. This 
A

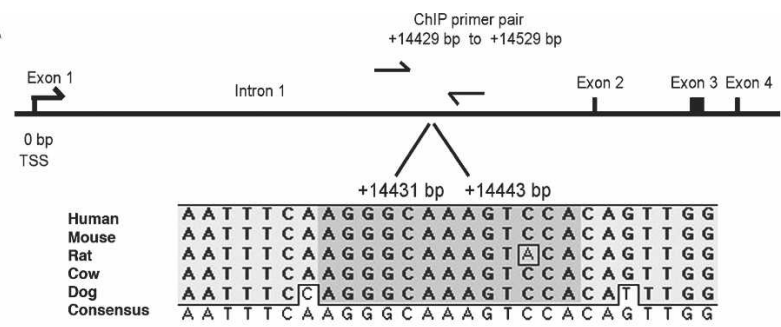

B

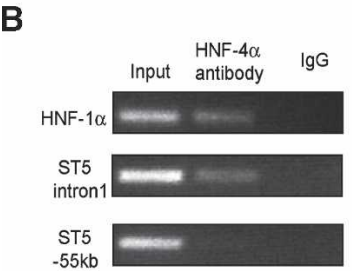

C HNF-4 $\alpha$ antibody - - + IgG
+14431 probe
+ Cold competitor - - - - + Nuclear Extract $\quad++++$

Supershift complex

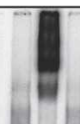

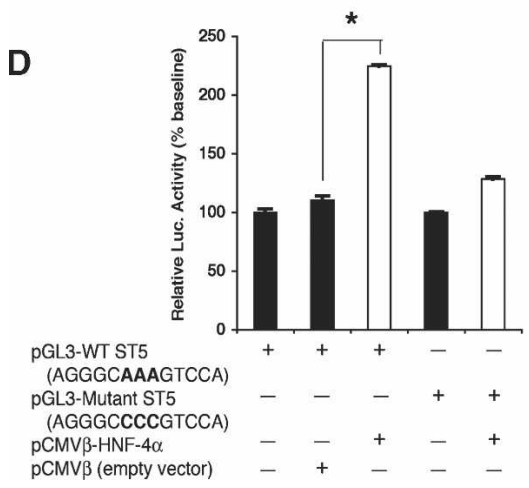

Figure 4. ST5 is a direct transcriptional target of HNF-4 $\alpha$ in vivo. (A) Genomic organization of the mouse ST5 locus with the evolutionarily conserved HNF- $4 \alpha$-binding site in intron 1 . The position of the binding site is indicated relative to the transcriptional start site (TSS). Arrows indicate the location of primer pairs used for Chip assays. (B) ChIP assays from isolated adult islets using an antibody raised against HNF- $4 \alpha$ reveal that HNF$4 \alpha$ occupies the intronic region of ST5 containing the highscoring HNF- $4 \alpha$-binding site (conserved in humans) but does not occupy the putative site $-55 \mathrm{~kb}$ upstream of the promoter. Primers amplifying the known HNF- $4 \alpha$-binding site in the $H N F-1 \alpha$ promoter serve as the positive control for the HNF- $4 \alpha$ ChIP assay. $(C)$ EMSA. Incubation of liver nuclear extract with a radiolabeled oligonucleotide containing the putative HNF- $4 \alpha$ binding sequence at intron 1 resulted in a strong shift of the radioactive band. The intensity of this band was diminished with the addition of an unlabeled competitor oligonucleotide containing a known HNF- $4 \alpha$-binding site. Addition of a HNF- $4 \alpha$ antibody generated a supershifted band that was not observed with the addition of preimmune serum, confirming the identity of the bound protein as HNF- $4 \alpha$. $(D)$ Cotransfection of BHK cells with HNF- $4 \alpha$ and pGL3-ST5, expressing luciferase under the control of a 192-bp fragment of the 3' conserved region of ST5 containing the HNF- $4 \alpha$-binding site, results in increased luciferase activity, indicating that this element serves as an HNF$4 \alpha$-dependent enhancer. Mutation of this binding site nearly abolishes the transcriptional activation. $\left(^{\star}\right) p$-value $<0.05$ by ANOVA; $n=3$ for each transfection condition. prompted us to compare the group of genes whose expression is dependent on HNF- $4 \alpha$ to the collection of genes found bound by HNF- $4 \alpha$ in pancreatic islets. There is significant overlap of orthologous genes between the platforms used by the location and expression analysis, allowing us to evaluate 4755 genes for which both data are available (Fig. 5A). First we evaluated the promoters occupied by RNA polymerase II, which served as the indicator for expressed genes in the global location analysis (Odom et al. 2004). Of these genes, $87 \%$ were expressed in control pancreatic islets, confirming both that the genome-wide location analysis using an antibody against RNA polymerase II accurately identified transcribed genes and that our expression profiling is sensitive enough to detect most genes whose promoters are occupied by RNA polymerase II, even those expressed at low copy number (Fig. 5B). However, for reasons unknown, RNA polymerase II location analysis only identified a fraction of the genes that are actually expressed in islets.

Next we determined the overlap between those genes whose promoters are occupied by HNF- $4 \alpha$ in islets and those whose expression is dependent on HNF-4 $\alpha$ in vivo (Fig. 5C). Our expression analysis identified 133 genes as HNF- $4 \alpha$-dependent and also represented on the promoter array used in the location analysis (Odom et al. 2004). Surprisingly, the overlap between differentially expressed genes and those bound by HNF- $4 \alpha$ is rather small. Thus, of 133 genes whose expression was dependent on HNF- $4 \alpha$, only 13 had been identified by the location analysis. Conversely, of the 587 promoters occupied by HNF- $4 \alpha, 574$ showed no statistically significant change in gene expression. The vast majority (433 or $86 \%$ ) had mRNA levels that are not altered appreciably in the absence of HNF- $4 \alpha$ (absolute change in expression was $<20 \%$ ), while only two exhibited induction or repression of more than twofold (Fig. 5D). Ten randomly selected genes implicated as HNF- $4 \alpha$ targets by location analysis were selected for determination of mRNA levels by real-time quantitative RT-PCR. Of these 10 genes, none showed significantly altered mRNA levels in the HNF- $4 \alpha$-deficient pancreatic islets when compared with control islets (data not shown). Thus, we propose that HNF- $4 \alpha$ functions in the pancreatic $\beta$-cell to regulate the expression of selected genes, and not as a controller of the global transcriptional program.

\section{Discussion}

HNF-4 $\alpha$ regulates physiological $\beta$-cell replication in response to increased metabolic demand

In this study, we investigated the molecular networks controlled by the MODY1 transcription factor HNF- $4 \alpha$ in pancreatic $\beta$-cells. Gene expression analysis revealed that numerous genes and pathways involved in the regulation of $\beta$-cell proliferation are dependent on HNF- $4 \alpha$. In our previous study, we reported that $H N F-4 \alpha^{\text {loxp } / 10 x}$ ${ }_{\mathrm{P}}$;Ins.Cre mice were glucose-intolerant due to impaired glucose-stimulated insulin secretion, but that $\beta$-cell 
A
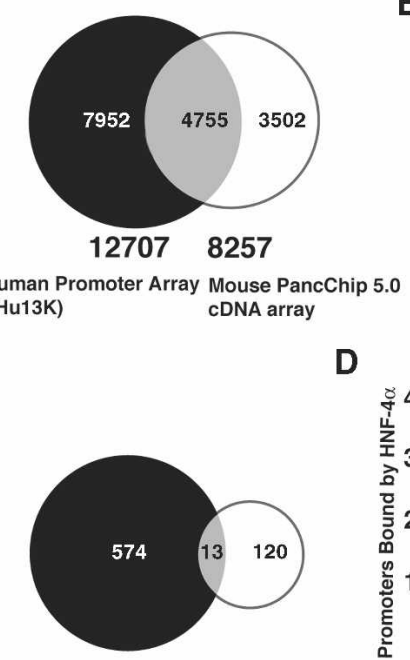

587

Promoters Bound by $\mathrm{HNF}-4 \alpha$
133 Genes whose expression
is dependent on HNF- $4 \alpha$
B
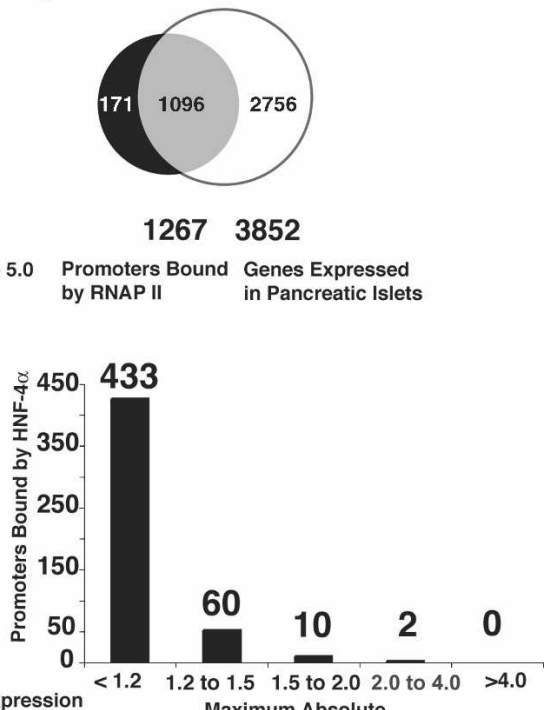

Maximum Absolute Fold change in Expression
Figure 5. Combining location and expression microarray analysis in pancreatic islets. $(A)$ Venn diagram displaying the overlap of orthologous genes between the two platforms compared in this analysis. The genes on the PancChip cDNA array are represented as the white circle, while the genes on the human promoter array are shown in black. Of the cDNAs represented on the PancChip, 4755 (the gray intersect) have orthologs for which the proximal promoter is present on the human promoter chip developed by Odom et al. (2004). (B) Venn diagram displaying the overlap of RNA polymerase II-bound promoters (black circles) and genes expressed in pancreatic islets identified by expression profiling (white circles). $(C)$ Venn diagram displaying the overlap of HNF $4 \alpha$-bound promoters (black circle) in pancreatic islets and genes differentially expressed (white) in islets lacking $\mathrm{HNF} 4 \alpha$ in $\beta$-cells. (D) Histogram of the absolute change in gene expression (either repression or induction) for 505 genes identified in the location analysis by Odom et al. (2004). mass at 4 mo of age is unaffected by the loss of HNF- $4 \alpha$ (Gupta et al. 2005). However, we could not exclude the possibility that HNF- $4 \alpha$ is required for the maintenance of $\beta$-cell mass under more stressful metabolic conditions, where mechanisms that promote $\beta$-cell expansion may differ from those that promote embryonic or postnatal $\beta$-cell maintenance. Similarly, the requirement for the MODY4 gene, encoding the Pdx-1 homeodomain transcription factor, for $\beta$-cell survival was uncovered only after mutant mice were metabolically challenged. $P d x-1^{+/-}$mice are more susceptible to $\beta$-cell apoptosis but exhibit a decrease in $\beta$-cell mass only when aged (Johnson et al. 2003). In addition, when $P d x-1^{+/-}$mice are bred to a background of insulin resistance, $\beta$-cell apoptosis increases (Kulkarni et al. 2004). Thus, based on our expression data, we hypothesized that $\beta$-cell expansion during increased metabolic demand is HNF- $4 \alpha$-dependent.

The pregnancy paradigm of $\beta$-cell expansion offers a highly reproducible model of physiological proliferation of $\beta$-cells. When compared with islets from pregnant $H N F-4 \alpha^{\operatorname{loxP} / \operatorname{loxP}}$ or $H N F-4 \alpha^{+/+}$;Ins.Cre controls, islets from $H N F-4 \alpha^{\operatorname{lox} / \operatorname{loxP}} ;$ Ins.Cre contained significantly fewer proliferative cells. Accordingly, $\beta$-cell mass is reduced in the pregnant HNF- $4 \alpha$ mutants, and glucose tolerance is further impaired. Numerous studies describe $\mathrm{HNF}-4 \alpha$ as a MODY gene and as a regulator of insulin secretion by the $\beta$-cell; however, the data presented here provide the first evidence that HNF- $4 \alpha$ is required in the $\beta$-cell for physiological expansion of $\beta$-cell mass. Thus, it is tempting to speculate that mutations in $H N F-4 \alpha$ result in diabetes, in part, through the failure to increase $\beta$-cell number.

Another implication of these results is that HNF- $4 \alpha$ may also be important for the prevention of gestational diabetes. Gestational diabetes mellitus is defined as glucose intolerance of various degrees that first presents during pregnancy (Buchanan and Xiang 2005). Several studies have revealed that mutations that cause MODY are also found in women with gestational diabetes, including mutations in the genes encoding glucokinase (MODY2), HNF-1 $\alpha$ (MODY3), and Pdx-1 (MODY4) (Ellard et al. 2000; Weng et al. 2002; Buchanan and Xiang 2005). Although these studies did not find a significant link between mutations in HNF- $4 \alpha$ and gestational diabetes, it is possible that loss-of-function mutations in this gene may be associated with an increased risk of this disease. Furthermore, we have found that islet mRNA levels of HNF- $4 \alpha$ increase during pregnancy, supporting a role for HNF- $4 \alpha$ in the $\beta$-cell's adaptation to pregnancy (data not shown). Thus, the data presented here suggest that future studies designed to identify linkage between common diabetes susceptibility genes and gestational diabetes should include screens for mutations in the gene encoding HNF- $4 \alpha$.

\section{Ras/ERK signaling in the $\beta$-cell is dependent on $H N F-4 \alpha$}

The data presented here demonstrate that HNF- $4 \alpha$ is required for proliferation induced by pregnancy, but that nonpregnant animals have the same $\beta$-cell mass. This supports the notion put forth by recent studies of p27 and Foxm 1 function in islets, which describe that mechanisms for embryonic or postnatal $\beta$-cell proliferation and differentiation are different from those driving expansion of adult islets (Rachdi et al. 2006; Zhang et al. 2006). What has become even more certain is that replication of existing $\beta$-cells is an important contributor to the maintenance and expansion of adult $\beta$-cell mass (Heit et al. 2006; Krishnamurthy et al. 2006). Lineage tracing experiments suggest that in mice few, if any, newly derived adult $\beta$-cells originate from progenitorcell differentiation (Dor et al. 2004). Many hormones and cytokines control the growth of the endocrine pancreas. 
The importance of the Ras/MAP /mitogen-activated protein) kinase signaling cascade in mediating the response to these growth factors and hormones in $\beta$-cells has been demonstrated by targeted disruption of a Ras guanine exchange factor, RasGRF1, which leads to a reduction in $\beta$-cell proliferation and $\beta$-cell mass (Font de Mora et al. 2003). In addition, activated ERK1/2 has also been suggested to mediate the $\beta$-cell response to pregnancy hormones (Amaral et al. 2003, 2004). GSEA led us to hypothesize that Ras/ERK signaling is attenuated in the HNF- $4 \alpha$ mutant islets. Indeed, levels of phosphorylated ERK1/2 were dramatically down-regulated in isolated islets of pregnant HNF- $4 \alpha$ mutants. In addition, mRNA levels of ST5 were significantly down-regulated in the HNF-4 $\alpha$ mutants. RNAi of ST5 expression in MIN6 cells resulted in diminished levels of phosphorylated ERK and thus identifies ST5 as a novel regulator of ERK signaling cascade in $\beta$-cells. Our binding site analysis, followed by ChIP assays and EMSA, identified an evolutionarily conserved HNF-4 $\alpha$-binding site in the first intron of ST5, indicating that HNF- $4 \alpha$ is a direct regulator of ST5 expression. While it is likely that other genes and pathways altered in the absence of HNF-4 $\alpha$ also contribute to the observed phenotype, we provide evidence that the decrease in $\beta$-cell proliferation observed in pregnant HNF$4 \alpha^{\text {loxP/loxP }}$;Ins.Cre mice is due, at least in part, to a reduction in Ras/ERK activation.

\section{HNF-4 $\alpha$ is not required to maintain global gene expression in the $\beta$-cell}

Previous location analysis, which combined ChIP with a custom DNA microarray containing portions of the promoter regions of 13,000 human genes, had identified thousands of genes occupied by HNF- $4 \alpha$ in liver and pancreatic islets (Odom et al. 2004). Relying solely on these binding data, Odom et al. (2004) proposed that HNF-4 $\alpha$ functions as a "master regulator" of transcription by regulating $>40 \%$ of the active promoters in the islet. Furthermore, Odom et al. (2004) propose that the loss of HNF- $4 \alpha$ in the $\beta$-cell leads to $\beta$-cell dysfunction due to misregulation of the global transcriptome. Gene expression profiling revealed a striking discordance between the genes whose mRNA levels are dependent on HNF- $4 \alpha$ in the $\beta$-cell, and those proposed as HNF- $4 \alpha$ targets by global location analysis, with only a small fraction of the genes identified by the promoter array showing changes in mRNA levels.

Location analysis has been successfully applied to yeast and mammalian tissues (Ren et al. 2000; Lee et al. 2002; Friedman et al. 2004; Phuc Le et al. 2005). However, our data demonstrate that location analysis for HNF- $4 \alpha$ captures only part of the transcriptional regulatory networks that are operative, while at the same time overestimating the number of regulatory relationships. An obvious reason for this difference between the situation in yeast and in mammalian tissues is the increased complexity of the metazoan genome and its regulatory circuits. Recently, using mouse genetics, Briancon and Weiss (2006) demonstrated that the activation domain of
HNF- $4 \alpha$ required for coactivator interaction is essential for HNF- $4 \alpha$ function in vivo. Thus, combinatorial action of multiple transcription factors and coactivators is required to effect the activation of a given target gene in metazoans (McKenna and O'Malley 2002). Another important issue is the fact that transcription factor binding has been shown to be uncoupled from transcriptional activation in many mammalian tissues, particularly the developing definite endoderm from which liver and pancreas are derived (Zaret 1999; Cirillo et al. 2002; Zaret 2002). In addition, the promoter array developed by Odom et al. (2004) contained elements that extend from position -700 to +200 bp relative to the transcriptional start site. Since elements binding tissue-specific or hormone-regulated transcription factors are often located in introns or regions far 5' and 3' to the transcriptional start site, such arrays only capture a small fraction of potential cis-regulatory elements. Thus, in addition to overestimating the number of regulatory relationships involving HNF-4 $\alpha$, location analysis alone also likely missed many potential HNF- $4 \alpha$ target genes, including those genes such as ST5 that are occupied by HNF- $4 \alpha$ at $>1 \mathrm{~kb}$ away from the transcriptional start site. While we cannot exclude the possibility that HNF- $4 \alpha$ contributes in part to the regulation of many of the genes identified by location analysis, our data indicate that HNF- $4 \alpha$ is not required to maintain global $\beta$-cell gene expression, thus challenging the conclusion by Odom et al. (2004) that the loss of HNF- $4 \alpha$ in $\beta$-cells leads to $\beta$-cell dysfunction through misregulation of global transcription.

In summary, by combining expression profiling with physiological analysis of $H N F-4 \alpha^{\operatorname{loxP} / \operatorname{loxP}} ;$ Ins.Cre mice, we have identified the HNF- $4 \alpha$-dependent transcriptional program in the pancreatic $\beta$-cell and have uncovered a novel role for HNF- $4 \alpha$ in the regulation of $\beta$-cell expansion. Our data clarify how HNF- $4 \alpha$ controls $\beta$-cell gene expression and highlight the importance of the simultaneous evaluation of transcription factor-binding sites and gene expression profiling of mutant tissue to fully capture the regulatory networks in mammalian transcriptional regulation.

\section{Materials and methods}

\section{Animals and genotype analysis}

The derivation of the $H N F-4 \alpha^{10 x P / / 10 x P}$; Ins.Cre mouse has been reported previously (Gupta et al. 2005). All mice were bred on the CD1 strain background. Genotyping was performed by PCR analysis using genomic DNA isolated from the tail tips of newborn mice. The gene expression profiling described here was focused on female mice because female $H N F-4 \alpha^{10 x P / l o x P}$; Ins.Cre mice showed larger impairments of glucose homeostasis when compared with age- and sex-matched controls on a standard diet than males (Gupta et al. 2005). Littermate $H N F-4 \alpha^{10 x P / / 0 x P}$ and $H N F-4 \alpha^{+/+}$; Ins.Cre female mice were used as controls. On the CD1 background, no detrimental effects of the Ins.Cre transgene were observed. All procedures involving mice were conducted in accordance with approved Institutional Animal Care and Use Committee protocols. 


\section{RNA isolation and real-time PCR analysis}

Islets from overnight fasted 18 -wk-old mice were isolated using the standard collagenase procedure as previously described. Total RNA from islets was isolated in Trizol (Invitrogen) according to the manufacturer's instructions. Islet RNA was reverse-transcribed using $1 \mu \mathrm{g}$ of Oligo(dT) primer, SuperScript II Reverse Transcriptase, and accompanying reagents (Invitrogen). PCR reaction mixes were assembled using the Brilliant SYBR Green QPCR Master Mix (Stratagene). Reactions were performed using the SYBR Green (with Dissociation Curve) program on the Mx4000 Multiplex Quantitative PCR System (Stratagene). All reactions were performed in triplicate with reference dye normalization, and median $\mathrm{C}_{\mathrm{T}}$ values were used for analysis. The primer sequences can be found at http://www.med.upenn.edu/ kaestnerlab. Islet purity was assessed as previously described and was determined to be $>90 \%$ endocrine tissue (Lantz et al. 2004).

\section{Microarray expression profiling and data analysis}

Two-hundred nanograms of total RNA of each sample were amplified using the MessageAmp aRNA Kit (Ambion, Inc.). All samples were analyzed before and after amplification using an Agilent Bioanalyzer Lab-On-A-Chip Nano 6000 chip to determine the integrity and concentration of the samples.

Two micrograms of amplified RNA were indirectly labeled using amino-allyl dUTP and random hexamers to prime reverse transcription. Fluorescent label (CyDye; Amersham Pharmacia Biotech Ltd.) was coupled to the cDNA and hybridized to the PancChip version 5.0 13K cDNA microarray (Scearce et al. 2002; Kaestner et al. 2003). For each sample, a dye swap hybridization was performed. The median intensities of each spot on the array were measured with an Agilent Scanner using the GenePix version 5 software, and the sample dye swap values were averaged to form one biological replicate. The data were normalized by the print tip lowess method using the SMA (Statistical Microarray Analysis) package in R (Yang et al. 2002). For statistical analysis, genes were called differentially expressed using the Significance Analysis of Microarrays (SAM) one class response package with a false discovery rate (FDR) of $10 \%$ (Tusher et al. 2001). Microarray data have been deposited in the MIAME-compliant database RNA abundance database (RAD) (Manduchi et al. 2004) and can be accessed at http://www. cbil.upenn.edu/RAD/php/queryStudy.php?study_id=1050. Microarray data will also be deposited to ArrayExpress.

\section{Gene Ontology analysis}

The software application Expression Analysis Systematic Explorer (EASE) was used to discover biologically relevant themes in the list of genes identified as significantly differentially expressed in the HNF-4 $\alpha$ mutants (Hosack et al. 2003; White et al. 2005). EASE was also used to identify functional categories statistically overrepresented in comparison to the number of genes in that category represented on the PancChip 5.0.

\section{Histological analyses}

For all histological studies, pancreata were dissected, fixed in $10 \%$ formalin for $24 \mathrm{~h}$, then laid flat for paraffin embedding. Paraffin sections with the largest tissue surface area were used in all experiments. Statistical analysis was performed by Student's $t$-test. For histological assessment of islet proliferation, mice were injected with $10 \mu \mathrm{L}$ of Zymed BrdU Solution $(3 \mathrm{mg} /$ $\mathrm{mL} \mathrm{BrdU}$; Zymed Laboratories) per gram of body weight $16 \mathrm{~h}$ prior to being sacrificed. BrdU staining was performed using the Zymed BrdU Staining Kit according to the manufacturer's instructions. BrdU-positive nuclei were counted blinded from at least 20 islets per mouse from four to six mice per group.

For insulin immunohistochemistry, slides were blocked with Avidin D and Biotin blocking reagents (Vector Laboratories) for $15 \mathrm{~min}$ at room temperature with a quick rinse of PBS in between. All slides were blocked with protein-blocking reagent (Immunotech) for $20 \mathrm{~min}$ at room temperature. The guinea pig anti-insulin antibody (1:200; Linco Research, Inc.) was diluted in PBT and incubated overnight at $4{ }^{\circ} \mathrm{C}$. Slides were washed in PBS and incubated with biotinylated anti-guinea pig antibody. HRP-conjugated Avidin-biotin complex reagent was used following the manufacturer's protocol (Vector). Signals were developed using $\mathrm{DAB}$ as substrate. For islet counting and $\beta$-cell mass determination, consecutive images covering the entire section were obtained, and islet cross-sectional area and total pancreas cross-sectional area were measured using MetaMorph Imaging Software (Universal Imaging Corp.).

\section{GSEA}

GSEA analysis was performed using the software package available at http://www.broad.mit.edu/gsea (Subramanian et al. 2005). All of the gene sets examined were obtained from the Molecular Signature Database C2, which includes 475 metabolic and signaling pathways derived from eight publicly available and manually curated databases, as well as 51 sets representing gene expression signatures of genetic and chemical perturbations previously described in the literature (Subramanian et al. 2005). To create the appropriate gene set file for PancChip 5.0, we modified the $\mathrm{C} 2$ database file, s2.moe430a.gmt, which uses Affymetrix probe IDs specific to the Affymetrix GeneChip Mouse Expression Set 430. Both the Affymetrix GeneChip Mouse Expression Set 430 and the PancChip probe IDs were annotated using EntrezGene identifiers where possible, allowing us to map the PancChip 5.0 EntrezGene identifiers to Affymetrix probe IDs to create a C2 database file for PancChip 5.0. For the GSEA analysis, we used the default parameters and 1000 permutations.

\section{Ras-GTP assays}

Levels of Ras-GTP were measured in freshly isolated islets of 3 to 5-mo-old virgin $H N F-4 \alpha^{\text {loxP/loxP }}$ and $H N F-4 \alpha^{\text {loxP/loxP }}$;ns.Cre mice using the Ras-GTP Chemi ELISA kit (Active Motif). Onehundred islets were lysed in $60 \mu \mathrm{L}$ of lysis/binding buffer and assayed for Ras-GTP according to the manufacturer's instructions.

\section{EGF treatment of islets and Western blot analysis}

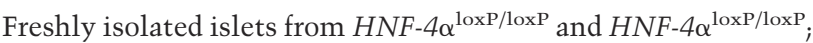
Ins.Cre mice were washed three times with Hanks buffer and preincubated in HEPES balanced salt solution (HBSS; 114 $\mathrm{mmol} / \mathrm{L} \mathrm{NaCl}, 4.7 \mathrm{mmol} / \mathrm{L} \mathrm{KCl}, 1.2 \mathrm{mmol} / \mathrm{L} \mathrm{KH} \mathrm{PO}_{4}, 1.16$ $\mathrm{mmol} / \mathrm{L} \mathrm{MgSO}_{4}, 20 \mathrm{mmol} / \mathrm{L}$ HEPES, $2.5 \mathrm{mmol} / \mathrm{L} \mathrm{CaCl}_{2}, 25.5$ $\mathrm{mmol} / \mathrm{L} \mathrm{NaHCO}, 0.2 \%$ bovine serum albumin at $\mathrm{pH} 7.2$ ) containing $3 \mathrm{mM}$ glucose for $2 \mathrm{~h}$ at $37^{\circ} \mathrm{C}$. Islets were then washed twice with PBS, and ERK phosphorylation was stimulated by adding $500 \mu \mathrm{L}$ of HBSS containing $50 \mathrm{ng} / \mathrm{mL}$ EGF or with vehicle for $5 \mathrm{~min}$ at $37^{\circ} \mathrm{C}$. Islets were transferred onto ice immediately, and lysed in $50 \mu \mathrm{L}$ of lysis buffer. Whole-cell extracts were prepared from EGF-treated islets or islets from pregnant mice by homogenization in lysis buffer containing $50 \mathrm{mM}$ Tris (pH 8.0), $150 \mathrm{mM} \mathrm{NaCl}, 1 \% \mathrm{NP}-40,0.5 \%$ sodium deoxycholic 
acid, $10 \mu \mathrm{g} / \mathrm{mL}$ bovine serum albumin, and $0.1 \%$ sodium dodecyl sulfate, supplemented with protease inhibitor cocktail (Sigma), and phosphatase inhibitor cocktail (Pierce). Total protein concentrations were determined by BCA assay (Pierce). Five micrograms of whole-cell lysate were separated by SDSPAGE and transferred to an immobilon P membrane (Millipore). For phosphorylated ERK1/2 immunoblots, membranes were blocked in $5 \% \mathrm{BSA} / 0.1 \%$ Tween in PBS for $30 \mathrm{~min}$, and then incubated overnight at $4^{\circ} \mathrm{C}$ with anti-phospho-ERK1/2 antibody (Cell Signaling \#9101) diluted 1:2000 in 5\% BSA/0.1\% Tween in PBS. For total ERK1/2 detection, membranes were blocked in $5 \%$ milk $/ 0.1 \%$ Tween in PBS for $30 \mathrm{~min}$, and then incubated for $3 \mathrm{~h}$ at room temperature with anti-ERK1/2 antibody (Cell Signaling \#9102) diluted 1:1000 in 5\% milk/0.1\% Tween in PBS. Proteins were visualized using the Immobilon Western Chemiluminescent HRP substrate (Millipore).

\section{RNAi in MIN6 cells}

Scrambled shRNA and ST5-specific shRNA sequences were designed using the Ambion online small interfering RNA (siRNA) target finder (http://www.ambion.com). Oligonucleotides encoding shRNA sequences were synthesized and cloned into the HindIII and BamHI restiction enzymes sites in the pSilencer 2.0 vector (Ambion). The U6 promoter along with the shRNA sequences were then cloned into the MfeI and EcoRI restriction enzyme sites of pShuttle (Clontech) to replace the CMV promoter and poly(A) sequence. The pShuttle plasmids containing the shRNA-U6 inserts were then used by the University of Pennsylania Viral Vector Core of the Gene Therapy Program to derive adenoviral vectors expressing the shRNA sequences under the control of the U6 promoter. Viral vectors were produced using a modified protocol of the Adeno-X Expression System (Clontech). Further details of viral vector production can be found at http://www.uphs.upenn.edu/penngen/gtp/ vcore_av.html. The scrambled shRNA sequence used in this study is as follows: Scrambled-shRNA, AAGCTTTTCCAA AAAACTACCGTTGTTATAGGTGTCTCTTGAACACCTATA ACAACGGTAGTGGATCC. For ST5 knockdown, two shRNA sequences were used as follows: ST5-shRNA\#4, AAGCTTTTC CAAAAAAGCCAAGCAATGGTCTACCTTCTCTTGAAAGGT AGACCATTGCTTGGCGGATCC $_{i}$ ST5-shRNA\#6, AAGCTT TTCCAAAAAAGCAATGGTCTACCTCСТTCTCTCTTGAAG AAGGAGGTAGACCATTGCGGATCC.

For ST5 loss-of-function analysis, $10^{6}$ MIN6 cells were cultured in six-well plates with $2 \mathrm{~mL}$ of DMEM (catalog \#10-013-

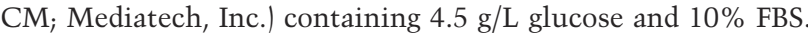
To each well, $10^{10}$ viral particles (either scrambled or a 1:1 mixture of ST5-siRNA\#4 and ST5-siRNA\#6) were added and incubated with the cells overnight at $37^{\circ} \mathrm{C}$. On the next morning, 2 $\mathrm{mL}$ of fresh medium were added to each well, and infection was continued for $48 \mathrm{~h}$. To stimulate ERK phosphorylation, cells were first washed twice with PBS followed by incubation in HBSS with $3 \mathrm{mM}$ glucose for $2 \mathrm{~h}$ at $37^{\circ} \mathrm{C}$. Fifty nanograms per milliliter EGF or vehicle were then added to cells, and cells were incubated for $5 \mathrm{~min}$ at $37^{\circ} \mathrm{C}$. Cells were immediately transferred on ice, lysed by $50 \mu \mathrm{L}$ of lysis buffer, and processed for Western blot analysis as described above.

Computational identification of HNF-4 $\alpha$-binding sites in the ST5 locus

In order to identify potential HNF- $4 \alpha$-binding sites in the ST5 locus, we first performed an alignment of all available mammalian sequences (mouse, rat, human) using the Vista Genome Browser (http://pipeline.lbl.gov/cgi-bin/gateway2). Sequences of conserved noncoding regions upstream of and downstream from the transcriptional start site were downloaded from the University of California at Santa Cruz Genome Browser. The Transcription Element Search System (TESS; http://www.cbi1.upenn.edu/tess) was used to identify HNF4- $\alpha$-binding sites in conserved regions. TESS located potential HNF- $4 \alpha$ transcription factor-binding sites using a log-likelihood cutoff of 12.5 The cutoff value was chosen by comparison to two background models (data not shown).

\section{Formaldehyde cross-linking and ChIP}

Seven-hundred hand-picked isolated islets from adult female CD1 mice were suspended in 1\% formaldehyde in PBS and were incubated for $10 \mathrm{~min}$ at room temperature while being rotated. Cross-linking was quenched by the addition of glycine to a final concentration of $0.125 \mathrm{M}$, with constant shaking, for an additional $5 \mathrm{~min}$. Islets were rinsed in cold PBS and lysed by rotating for $15 \mathrm{~min}$ at $4^{\circ} \mathrm{C}$ in $700 \mu \mathrm{L}$ of cell lysis buffer $(10 \mathrm{mM}$ Tris-Cl at $\left.\mathrm{pH} 8.0,10 \mathrm{mM} \mathrm{NaCl}, 3 \mathrm{mM} \mathrm{MgCl}_{2}, 0.5 \% \mathrm{NP}-40\right)$ supplemented with protease inhibitors (Roche \#0). Sonication was performed with a Sonic Dismembrator model 100 sonicator (Fisher Scientific) with a microtip probe set to a power output of 4-6 W for three cycles of $20 \mathrm{sec}$ each. Insoluble debris was removed by centrifugation at $13,000 \mathrm{~g}$ for $10 \mathrm{~min}$ at $4^{\circ} \mathrm{C}$, and the supernatant was collected and flash-frozen in liquid nitrogen. Cross-linking was reversed for a $50-\mu \mathrm{L}$ aliquot by the addition of $\mathrm{NaCl}$ to a final concentration of $192 \mathrm{mM}$, overnight incubation at $65^{\circ} \mathrm{C}$, and purification using a Minelute PCR purification kit (Qiagen). For immunoprecipitations, $650 \mu \mathrm{L}$ of cross-linked chromatin was precleared by incubation for $1 \mathrm{~h}$ at $4^{\circ} \mathrm{C}$ with $125 \mu \mathrm{L}$ of protein G-agarose (Upstate Biotechnology) in a total volume of $1 \mathrm{~mL}$ of ChIP dilution buffer $(20 \mathrm{mM}$ Tris- $\mathrm{HCl}$ at $\mathrm{pH} 8.1,1 \%$ Triton X-100, 2 mM EDTA, $150 \mathrm{mM} \mathrm{NaCl}$ ). After this preclearing, the supernatant was evenly divided and incubated overnight with $2 \mu \mathrm{g}$ of HNF-4 $\alpha$ antibody (sc-6556; Santa Cruz Biotechnology) or control IgG. Immunoprecipitation was performed as described (Rubins et al. 2005). The precipitated and un-cross-linked DNA was purified on a Minelute purification column and eluted in $30 \mu \mathrm{L}$ of $10 \mathrm{mM}$ Tris $(\mathrm{pH}$ 8.5). The primer sequences for PCR are available upon request.

\section{EMSA}

Oligonucleotides were synthesized corresponding to the HNF$4 \alpha$-binding site in the ST5 gene located in intron 1. Radiolabeled probes were generated by incubation of $250 \mathrm{ng}$ of annealed oligonucleotides with $20 \mu \mathrm{Ci}$ of $\left[{ }^{32} \mathrm{P}\right] \mathrm{dCTP}$ in the presence of Klenow DNA Polymerase (Roche Applied Science) for $15 \mathrm{~min}$ at $37^{\circ} \mathrm{C}$. Radiolabeled probes were subsequently separated from free nucleotide using G-50 column purification (Amersham). Liver nuclear extract was then incubated for $15 \mathrm{~min}$ at room temperature with $100,000 \mathrm{dpm}$ of radiolabeled probe and $1 \mu \mathrm{g}$ of poly(dI-dC) in $10 \mathrm{mM}$ Tris- $\mathrm{HCl}(\mathrm{pH} 7.5), 50 \mathrm{mM} \mathrm{NaCl}, 1 \mathrm{mM}$ DTT, $1 \mathrm{mM}$ EDTA, and 5\% glycerol. Some binding reactions were subsequently incubated with anti-HNF- $4 \alpha$ antibody (Santa Cruz Biotechnology sc-6556) for $30 \mathrm{~min}$ at room temperature. Samples were resolved on $5 \%$ polyacrylamide gels in $0.5 \%$ TBE at $300 \mathrm{~V}$ for $2 \mathrm{~h}$. The dried gel was exposed to a PhosphorImager cassette (Amersham) and analyzed with Storm840 software (Amersham). The oligonucleotide sequences for the HNF-4a site in the ST5 gene were as follows: Forward, 5'-GGG GATTTCAAGGGCAAAGTCCACAGTTG-3'; Reverse, 5' GGGGCAACTGTGGACTTTGCCCTTGAAAT-3'. 


\section{Transient transfections and luciferase reporter assays}

A 192-bp fragment $(+14,298$ to $+14,489$ relative to the TSS $)$ of the $3^{\prime}$ conserved region of ST5 containing the HNF- $4 \alpha$-binding site was PCR-cloned to contain KpnI and BglII restriction enzyme sites on the $5^{\prime}$ and $3^{\prime}$ ends, respectively. A mutated version of this element was generated by overlap PCR (Fig. 4D). The wild-type and mutant PCR fragments were then cloned into the KpnI and BglII sites of the pGL3 promoter luciferase vector (Promega). pCMV $\beta$-HNF $4 \alpha$ (a kind gift of Dr. M. Stoffel, Zurich, Switzerland) was used to expresses Flag-tagged HNF- $4 \alpha$ under the control of the cytomegalovirus promoter. BHK cells $\left(5 \times 10^{5}\right)$ were seeded $16 \mathrm{~h}$ prior to transfection in $60-\mathrm{mm}$ dishes and cultured in DMEM supplemented with $10 \%$ fetal bovine serum, L-glutamine, penicillin, and streptomycin. Transient transfections were performed using the Effectine transfection reagent (Qiagen) according to the manufacturer's instructions. Twenty-four hours after transfection, cells were harvested, and luciferase activity was measured using the Dual Luciferase Reporter Assay (Promega). Luciferase activity was normalized for transfection efficiency by the corresponding Renilla luciferase activity. The primer sequences are available upon request.

\section{Orthology relationships}

Mapping from the genes on the human promoter array to their mouse orthologs represented on the PancChip 5.0 was done using the public genome databases. First, human and mouse orthology information retrieved from the Mouse Genome Informatics (MGI) database (Blake et al. 2003) was used to relate the human genes, identified by NCBI RefSeq accessions, to MGI IDs for an orthologous mouse gene. We also used human Entrez Gene IDs from NCBI's curated Entrez Gene (Pruitt and Maglott 2001) database to map to MGI. We supplemented the set of orthologs found using the MGI database with those in NCBI HomoloGene database. Finally, several unmapped genes were manually assigned using the orthologous mouse gene as annotated by Odom et al. (2004) in their Supplemental Material. The Hu13k array contains promoters for 12,707 unique RefSeqs. Our searches resulted in orthologs for 11,318 distinct genes on the Human promoter array.

Mouse PancChip 5.0 annotation is derived from three sources: (1) DoTS, the Database of Transcribed Sequences for human and mouse genes provided by the Computational Biology and Informatics Laboratory (Center for Bioinformatics, University of Pennsylvania; http://www.cbil.upenn.edu/downloads/DoTS, http://www.allgenes.org; Zhu et al. 2003); (2) UniGene, a database that clusters GenBank sequences into a nonredundant set of gene-oriented clusters; and (3) BLAST analysis of the array EST sequences to the set of mouse mRNAs available from MGI and the RefSeq collection. These sources are then linked to an Entrez Gene identifier. Thus, annotation for PancChip 5.0 includes the MGI and Entrez Gene information, DoTS transcript information, and Mouse RefSeq accessions. The PancChip 5.0 MGI ID and Entrez Gene ID were searched for the mouse orthologs to the human genes represented on the Hu13K array. We found 4755 distinct genes from Hu13k array to have corresponding mouse orthologs on PancChip 5.0.

\section{Acknowledgments}

We thank Drs. Morris J. Birnbaum, Joshua Friedman, and Catherine Lee May for critical reading of the manuscript and useful discussions. We thank Sophia Hammani and James Fulmer for maintaining our mice, Drs. Jonathan Schug and Elisa- betta Manducchi for help with the bioinformatics analysis, Dr. Ed Williamson for assistance with $\beta$-cell mass determination, Dr. Heather Collins for performing radioimmune assays, Dr. Gary Swain and the University of Pennsylvania Morphology core for assistance with histology, and Dr. Nir Rubins for assistance with EMSA. We are also grateful to Dr. Arbans K. Sandhu and the University of Pennsylvania Vector Core Facility for deriving the adenoviral vectors used in this study. This work was supported by NIDDK grants DK55342 and DK56947, and the PENN Diabetes and Endocrinology Research Center (NIH DK19525).

\section{References}

Ahlgren, U., Jonsson, J., Jonsson, L., Simu, K., and Edlund, H. 1998. $\beta$-Cell-specific inactivation of the mouse $\operatorname{Ipf} 1 / \mathrm{Pdx} 1$ gene results in loss of the $\beta$-cell phenotype and maturity onset diabetes. Genes \& Dev. 12: 1763-1768.

Amaral, M.E., Ueno, M., Carvalheira, J.B., Carneiro, E.M., Velloso, L.A., Saad, M.J., and Boschero, A.C. 2003. Prolactinsignal transduction in neonatal rat pancreatic islets and interaction with the insulin-signaling pathway. Horm. Metab. Res. 35: 282-289.

Amaral, M.E., Cunha, D.A., Anhe, G.F., Ueno, M., Carneiro, E.M., Velloso, L.A., Bordin, S., and Boschero, A.C. 2004. Participation of prolactin receptors and phosphatidylinositol 3-kinase and MAP kinase pathways in the increase in pancreatic islet mass and sensitivity to glucose during pregnancy. J. Endocrinol. 183: 469-476.

Blake, J.A., Richardson, J.E., Bult, C.J., Kadin, J.A., and Eppig, J.T. 2003. MGD: The Mouse Genome Database. Nucleic Acids Res. 31: 193-195.

Briancon, N. and Weiss, M.C. 2006. In vivo role of the HNF $4 \alpha$ AF-1 activation domain revealed by exon swapping. EMBO $J$. 25: 1253-1262.

Buchanan, T.A. and Xiang, A.H. 2005. Gestational diabetes mellitus. J. Clin. Invest. 115: 485-491.

Burns, C.J., Squires, P.E., and Persaud, S.J. 2000. Signaling through the p38 and p42/44 mitogen-activated families of protein kinases in pancreatic $\beta$-cell proliferation. Biochem. Biophys. Res. Commun. 268: 541-546.

Cirillo, L.A., Lin, F.R., Cuesta, I., Friedman, D., Jarnik, M., and Zaret, K.S. 2002. Opening of compacted chromatin by early developmental transcription factors HNF3 (FoxA) and GATA-4. Mol. Cell 9: 279-289.

Dor, Y., Brown, J., Martinez, O.I., and Melton, D.A. 2004. Adult pancreatic $\beta$-cells are formed by self-duplication rather than stem-cell differentiation. Nature 429: 41-46.

Ellard, S., Beards, F., Allen, L.I., Shepherd, M., Ballantyne, E., Harvey, R., and Hattersley, A.T. 2000. A high prevalence of glucokinase mutations in gestational diabetic subjects selected by clinical criteria. Diabetologia 43: 250-253.

Finegood, D.T., Scaglia, L., and Bonner-Weir, S. 1995. Dynamics of $\beta$-cell mass in the growing rat pancreas. Estimation with a simple mathematical model. Diabetes 44: 249-256.

Font de Mora, J., Esteban, L.M., Burks, D.J., Nunez, A., Garces, C., Garcia-Barrado, M.J., Iglesias-Osma, M.C., Moratinos, J., Ward, J.M., and Santos, E. 2003. Ras-GRF1 signaling is required for normal $\beta$-cell development and glucose homeostasis. EMBO J. 22: 3039-3049.

Friedman, J.R., Larris, B., Le, P.P., Peiris, T.H., Arsenlis, A., Schug, J., Tobias, J.W., Kaestner, K.H., and Greenbaum, L.E. 2004. Orthogonal analysis of C/EBP $\beta$ targets in vivo during liver proliferation. Proc. Natl. Acad. Sci. 101: 12986-12991.

Fukui, K., Yang, Q., Cao, Y., Takahashi, N., Hatakeyama, H., 
Wang, H., Wada, J., Zhang, Y., Marselli, L., Nammo, T., et al. 2005. The HNF-1 target collectrin controls insulin exocytosis by SNARE complex formation. Cell Metab. 2: 373-384.

Gupta, R.K., Vatamaniuk, M.Z., Lee, C.S., Flaschen, R.C., Fulmer, J.T., Matschinsky, F.M., Duncan, S.A., and Kaestner, K.H. 2005. The MODY1 gene HNF- $4 \alpha$ regulates selected genes involved in insulin secretion. J. Clin. Invest.

Hagenfeldt-Johansson, K.A., Herrera, P.L., Wang, H., Gjinovci, A., Ishihara, H., and Wollheim, C.B. 2001. $\beta$-Cell-targeted expression of a dominant-negative hepatocyte nuclear factor- $1 \alpha$ induces a maturity-onset diabetes of the young (MODY)3-like phenotype in transgenic mice. Endocrinology 142: $5311-5320$.

Hayhurst, G.P., Lee, Y.H., Lambert, G., Ward, J.M., and Gonzalez, F.J. 2001. Hepatocyte nuclear factor $4 \alpha$ (nuclear receptor $2 \mathrm{~A} 1$ ) is essential for maintenance of hepatic gene expression and lipid homeostasis. Mol. Cell. Biol. 21: 1393-1403.

Heit, J.J., Apelqvist, A.A., Gu, X., Winslow, M.M., Neilson, J.R., Crabtree, G.R., and Kim, S.K. 2006. Calcineurin/NFAT signalling regulates pancreatic $\beta$-cell growth and function. $\mathrm{Na}$ ture 443: 345-349.

Hosack, D.A., Dennis Jr., G., Sherman, B.T., Lane, H.C., and Lempicki, R.A. 2003. Identifying biological themes within lists of genes with EASE. Genome Biol. 4: R70.

Johnson, J.D., Ahmed, N.T., Luciani, D.S., Han, Z., Tran, H., Fujita, J., Misler, S., Edlund, H., and Polonsky, K.S. 2003. Increased islet apoptosis in $\mathrm{Pdx}^{+/-}$mice. J. Clin. Invest. 111: $1147-1160$.

Jonsson, J., Carlsson, L., Edlund, T., and Edlund, H. 1994. Insulin-promoter-factor 1 is required for pancreas development in mice. Nature 371: 606-609.

Kaestner, K.H., Lee, C.S., Scearce, L.M., Brestelli, J.E., Arsenlis, A., Le, P.P., Lantz, K.A., Crabtree, J., Pizarro, A., Mazzarelli, J., et al. 2003. The transcriptional program of the endocrine pancreas. Diabetes 52: 1604-1610.

Krishnamurthy, J., Ramsey, M.R., Ligon, K.L., Torrice, C., Koh, A., Bonner-Weir, S., and Sharpless, N.E. 2006. p16 ${ }^{\text {INK4a }}$ induces an age-dependent decline in islet regenerative potential. Nature 443: 453-457.

Kulkarni, R.N., Jhala, U.S., Winnay, J.N., Krajewski, S., Montminy, M., and Kahn, C.R. 2004. PDX-1 haploinsufficiency limits the compensatory islet hyperplasia that occurs in response to insulin resistance. J. Clin. Invest. 114: 828-836.

Lantz, K.A., Vatamaniuk, M.Z., Brestelli, J.E., Friedman, J.R., Matschinsky, F.M., and Kaestner, K.H. 2004. Foxa2 regulates multiple pathways of insulin secretion. J. Clin. Invest. 114: 512-520.

Lee, T.I., Rinaldi, N.J., Robert, F., Odom, D.T., Bar-Joseph, Z., Gerber, G.K., Hannett, N.M., Harbison, C.T., Thompson, C.M., Simon, I., et al. 2002. Transcriptional regulatory networks in Saccharomyces cerevisiae. Science 298: 799-804.

Li, Y., Hansotia, T., Yusta, B., Ris, F., Halban, P.A., and Drucker, D.J. 2003. Glucagon-like peptide-1 receptor signaling modulates $\beta$ cell apoptosis. J. Biol. Chem. 278: 471-478.

Lichy, J.H., Majidi, M., Elbaum, J., and Tsai, M.M. 1996. Differential expression of the human ST5 gene in HeLa-fibroblast hybrid cell lines mediated by YY1: Evidence that YY1 plays a part in tumor suppression. Nucleic Acids Res. 24: 47004708.

Lu, Y., Herrera, P.L., Guo, Y., Sun, D., Tang, Z., LeRoith, D., and Liu, J.L. 2004. Pancreatic-specific inactivation of IGF-I gene causes enlarged pancreatic islets and significant resistance to diabetes. Diabetes 53: 3131-3141.

Majidi, M., Hubbs, A.E., and Lichy, J.H. 1998. Activation of extracellular signal-regulated kinase 2 by a novel Abl-binding protein, ST5. J. Biol. Chem. 273: 16608-16614.
Manduchi, E., Grant, G.R., He, H., Liu, J., Mailman, M.D., Pizarro, A.D., Whetzel, P.L., and Stoeckert Jr., C.J. 2004. RAD and the RAD Study-Annotator: An approach to collection, organization and exchange of all relevant information for high-throughput gene expression studies. Bioinformatics 20: 452-459.

McKenna, N.J. and O'Malley, B.W. 2002. Combinatorial control of gene expression by nuclear receptors and coregulators. Cell 108: 465-474.

Miura, A., Yamagata, K., Kakei, M., Hatakeyama, H., Takahashi, N., Fukui, K., Nammo, T., Yoneda, K., Inoue, Y., Sladek, F.M., et al. 2006. Hepatocyte nuclear factor- $4 \alpha$ is essential for glucose-stimulated insulin secretion by pancreatic ß-cells. J. Biol. Chem. 281: 5246-5257.

Odom, D.T., Zizlsperger, N., Gordon, D.B., Bell, G.W., Rinaldi, N.J., Murray, H.L., Volkert, T.L., Schreiber, J., Rolfe, P.A., Gifford, D.K., et al. 2004. Control of pancreas and liver gene expression by HNF transcription factors. Science 303: 13781381.

Parsons, J.A., Brelje, T.C., and Sorenson, R.L. 1992. Adaptation of islets of Langerhans to pregnancy: Increased islet cell proliferation and insulin secretion correlates with the onset of placental lactogen secretion. Endocrinology 130: 1459-1466.

Parviz, F., Matullo, C., Garrison, W.D., Savatski, L., Adamson, J.W., Ning, G., Kaestner, K.H., Rossi, J.M., Zaret, K.S., and Duncan, S.A. 2003. Hepatocyte nuclear factor $4 \alpha$ controls the development of a hepatic epithelium and liver morphogenesis. Nat. Genet. 34: 292-296.

Phuc Le, P., Friedman, J.R., Schug, J., Brestelli, J.E., Parker, J.B., Bochkis, I.M., and Kaestner, K.H. 2005. Glucocorticoid receptor-dependent gene regulatory networks. PLoS Genet. 1: e16.

Pruitt, K.D. and Maglott, D.R. 2001. RefSeq and LocusLink: NCBI gene-centered resources. Nucleic Acids Res. 29: 137140.

Rachdi, L., Balcazar, N., Elghazi, L., Barker, D.J., Krits, I., Kiyokawa, H., and Bernal-Mizrachi, E. 2006. Differential effects of p27 in regulation of $\beta$-cell mass during development, neonatal period, and adult life. Diabetes 55: 3520-3528.

Ren, B., Robert, F., Wyrick, J.J., Aparicio, O., Jennings, E.G., Simon, I., Zeitlinger, J., Schreiber, J., Hannett, N., Kanin, E., et al. 2000. Genome-wide location and function of DNA binding proteins. Science 290: 2306-2309.

Rubins, N.E., Friedman, J.R., Le, P.P., Zhang, L., Brestelli, J., and Kaestner, K.H. 2005. Transcriptional networks in the liver: Hepatocyte nuclear factor 6 function is largely independent of Foxa2. Mol. Cell. Biol. 25: 7069-7077.

Scearce, L.M., Brestelli, J.E., McWeeney, S.K., Lee, C.S., Mazzarelli, J., Pinney, D.F., Pizarro, A., Stoeckert Jr., C.J., Clifton, S.W., Permutt, M.A., et al. 2002. Functional genomics of the endocrine pancreas: The pancreas clone set and PancChip, new resources for diabetes research. Diabetes 51: 1997-2004.

Shih, D.Q. and Stoffel, M. 2002. Molecular etiologies of MODY and other early-onset forms of diabetes. Curr. Diab. Rep. 2: $125-134$.

Subramanian, A., Tamayo, P., Mootha, V.K., Mukherjee, S., Ebert, B.L., Gillette, M.A., Paulovich, A., Pomeroy, S.L., Golub, T.R., Lander, E.S., et al. 2005. Gene set enrichment analysis: A knowledge-based approach for interpreting genome-wide expression profiles. Proc. Natl. Acad. Sci. 102: 15545-15550.

Tusher, V.G., Tibshirani, R., and Chu, G. 2001. Significance analysis of microarrays applied to the ionizing radiation response. Proc. Nat1. Acad. Sci. 98: 5116-5121.

Wang, H., Maechler, P., Hagenfeldt, K.A., and Wollheim, C.B. 1998. Dominant-negative suppression of HNF-1 $\alpha$ function 
results in defective insulin gene transcription and impaired metabolism-secretion coupling in a pancreatic $\beta$-cell line. EMBO I. 17: 6701-6713.

Wang, H., Maechler, P., Antinozzi, P.A., Hagenfeldt, K.A., and Wollheim, C.B. 2000. Hepatocyte nuclear factor $4 \alpha$ regulates the expression of pancreatic $\beta$-cell genes implicated in glucose metabolism and nutrient-induced insulin secretion. $J$. Biol. Chem. 275: 35953-35959.

Wang, L., Coffinier, C., Thomas, M.K., Gresh, L., Eddu, G., Manor, T., Levitsky, L.L., Yaniv, M., and Rhoads, D.B. 2004. Selective deletion of the HNF1 $\beta$ (MODY5) gene in $\beta$-cells leads to altered gene expression and defective insulin release. Endocrinology 145: 3941-3949.

Weng, J., Ekelund, M., Lehto, M., Li, H., Ekberg, G., Frid, A., Aberg, A., Groop, L.C., and Berntorp, K. 2002. Screening for MODY mutations, GAD antibodies, and type 1 diabetesassociated HLA genotypes in women with gestational diabetes mellitus. Diabetes Care 25: 68-71.

White, P., Brestelli, J.E., Kaestner, K.H., and Greenbaum, L.E. 2005. Identification of transcriptional networks during liver regeneration. J. Biol. Chem. 280: 3715-3722.

Wilson, M.E., Scheel, D., and German, M.S. 2003. Gene expression cascades in pancreatic development. Mech. Dev. 120: 65-80.

Yang, Y.H., Dudoit, S., Luu, P., Lin, D.M., Peng, V., Ngai, J., and Speed, T.P. 2002. Normalization for cDNA microarray data: A robust composite method addressing single and multiple slide systematic variation. Nucleic Acids Res. 30: e15.

Zaret, K. 1999. Developmental competence of the gut endoderm: Genetic potentiation by GATA and HNF3/fork head proteins. Dev. Biol. 209: 1-10.

Zaret, K.S. 2002. Regulatory phases of early liver development: Paradigms of organogenesis. Nat. Rev. Genet. 3: 499-512.

Zhang, H., Ackermann, A.M., Gusarova, G.A., Lowe, D., Feng, X., Kopsombut, U.G., Costa, R.H., and Gannon, M. 2006. The FoxM1 transcription factor is required to maintain pancreatic $\beta$-cell mass. Mol. Endocrinol. 20: 1853-1866.

Zhu, Y., King, B.L., Parvizi, B., Brunk, B.P., Stoeckert Jr., C.J., Quackenbush, J., Richardson, J., and Bult, C.J. 2003. Integrating computationally assembled mouse transcript sequences with the Mouse Genome Informatics (MGI) database. Genome Biol. 4: R16.

Zimmet, P., Alberti, K.G., and Shaw, J. 2001. Global and societal implications of the diabetes epidemic. Nature 414: 782787. 


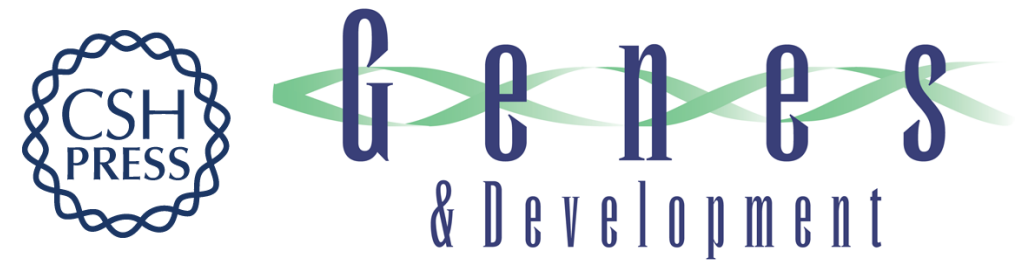

\section{Expansion of adult $\beta$-cell mass in response to increased metabolic demand is dependent on HNF-4 $\alpha$}

Rana K. Gupta, Nan Gao, Regina K. Gorski, et al.

Genes Dev. 2007, 21:

Access the most recent version at doi:10.1101/gad.1535507

\section{Supplemental http://genesdev.cshlp.org/content/suppl/2007/03/19/21.7.756.DC1 Material}

\section{Related Content}

Adult Organ Growth

Nancy R. Gough

Sci. STKE April , 2007 2007: tw129

References This article cites 56 articles, 23 of which can be accessed free at: http://genesdev.cshlp.org/content/21/7/756.full.html\#ref-list-1

Articles cited in:

http://genesdev.cshlp.org/content/21/7/756.full.html\#related-urls

\section{License}

Email Alerting Service
Receive free email alerts when new articles cite this article - sign up in the box at the top right corner of the article or click here.

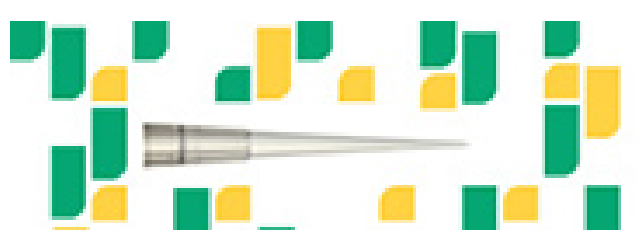

Focused on your science. 